\title{
Curcumin (1,7-bis(4-hydroxy-3-methoxyphenyl)-1, 6-heptadiene-3,5-dione) Blocks the Chemotaxis of Neutrophils by Inhibiting Signal Transduction through IL-8 Receptors
}

\author{
Masafumi Takahashi, ${ }^{1}$ Takatoshi Ishiko, ${ }^{1}$ Hidenobu Kamohara, ${ }^{1}$ Hideaki Hidaka, ${ }^{2}$ Osamu Ikeda, ${ }^{1}$ \\ Michio Ogawa, ${ }^{3}$ and Hideo Baba ${ }^{1}$ \\ ${ }^{1}$ Department of Gastroenterological Surgery, Graduate School of Medical Sciences, Kumamoto University, \\ Honjo 1-1-1, Kumamoto 860-8556, Japan \\ ${ }^{2}$ Department of Surgery II, Faculty of Medicine, University of Miyazaki, Miyazaki-shi, Miyazaki 889-2192, Japan \\ ${ }^{3}$ Department of Surgery, Kumamoto Rousai Hospital, Yatsushiro 866-8533, Japan
}

Received 22 October 2006; Revised 24 January 2007; Accepted 5 April 2007

\begin{abstract}
We investigated the impact of curcumin on neutrophils. Chemotactic activity via human recombinant IL-8 (hrIL-8) was significantly inhibited by curcumin. Curcumin reduced calcium ion flow induced by internalization of the IL- 8 receptor. We analyzed flow cytometry to evaluate the status of the IL-8 receptor after curcumin treatment. The change in the distribution of receptors intracellularly and on the cell surface suggested that curcumin may affect the receptor trafficking pathway intracellulary. Rab11 is a low molecular weight $\mathrm{G}$ protein associated with the CXCR recycling pathway. Following curcumin treatment, immunoprecipitation studies showed that the IL- 8 receptor was associated with larger amounts of active Rab11 than that in control cells. These data suggest that curcumin induces the stacking of the Rab11 vesicle complex with CXCR1 and CXCR2 in the endocytic pathway. The mechanism for antiinflammatory response by curcumin may involve unique regulation of the Rab11 trafficking molecule in recycling of IL-8 receptors.
\end{abstract}

Copyright (C) 2007 Masafumi Takahashi et al. This is an open access article distributed under the Creative Commons Attribution License, which permits unrestricted use, distribution, and reproduction in any medium, provided the original work is properly cited.

\section{INTRODUCTION}

Curcumin (17-bis (4-hydroxy-3-methoxyphenyl)-1,6-heptadiene-3,5-dione) extracted from Curcuma longa L. is generally used as a spice and as a coloring agent in food $[1,2]$. Curcumin is also used in traditional medicine to treat the inflammatory diseases [3].

Curcumin has anti-inflammatory and antioxidant effects and downregulates chemokine expression in inflammatory cells $[1,4,5]$. Curcumin affects kinase reactions, such as those of MAP kinase, and PKC, c-Jun/AP-1 [6, 7]. Furthermore, several researchers, including our group, have reported that curcumin blocks NF-kB activity during transcription $[8,9]$. The molecular mechanism of NF-kB inhibition involves the blocking of IkB phosphorylation in a human nontransforming epithelial cell line $[9,10]$. Although the inhibitory effect of curcumin on inflammatory responses is well known $[11,12]$, the contribution of curcumin to the signal transduction pathway in the proinflammatory cytokine response remains unclear.
IL-8 belongs to the CXC chemokine subgroup. It is a chemotactic cytokine that activates and elicits the migration of leukocyte [13]. IL-8 affects the functions of human neutrophils, including enhanced chemotaxis, enzyme release, and expression of surface adhesion molecules. IL-8 stimulates neutrophils via specific chemokine receptors, namely, the IL-8 receptors. These receptors are seven-transmembrane guanine nucleotide-binding proteincoupled receptors (GPCRs). IL-8 receptors are membranebound proteins expressed in large amount in primary cultured neutrophils. Humans have two high-affinity receptors for IL-8, namely, CXCR1 and CXCR2. The sequences of these receptors show 77\% homology $[13,14]$. Receptormediated signal transduction is initiated by coupling with heterotrimeric $G$ proteins, and this results in an increase in the cytosolic free $\mathrm{Ca}^{2+}$ concentration due to activation by IL-8 $[14,15]$. CXCR1 has limited activators, such as IL-8; however, CXCR2 has numerous activator cytokines, that is, CXC chemokines such as NAP-2 and GRO $\alpha[16,17]$. Recent evidence has suggested that IL-8 receptors internalize 
via clathrin-coated vesicle upon agonist binding $[18,19]$. After the release of the agonist, the IL- 8 receptors are transported from the cytoplasm to the nucleus; some of the receptors are transported back to the cell surface via the recycling endosomes. This phenomenon is termed as "recycling." CXCR1 is recycled to the cell surface more rapidly than CXCR2 $[17,19-22]$. It was reported that CXCR1 is the dominant mediator of the neutrophil chemotactic response to IL-8 [23]. Thus, CXCR1 is involved in the crucial process of neutrophil-induced inflammation.

We previously reported that IL-8 and its receptors were constitutively produced by pancreatic cancer cells. In addition, the autocrine growth effect of IL- 8 is blocked by curcumin [8]. In this process, curcumin contributes not only to the inhibition of IL- 8 production but also to the inhibition of signal transduction via IL-8 receptors. These data suggested that curcumin is a potent agent that blocks the IL- 8 receptormediated neutrophil responses.

In this study, we investigated the effect of curcumin on neutrophil chemotaxis mediated by IL- 8 and determined whether curcumin treatment inhibits signal transduction from the IL-8 receptor in human primary neutrophils. We designed the study in order to test the hypothesis that curcumin treatment has an effect on the endosomal trafficking pathway of IL-8 receptors.

Therefore, the endosomal vesicles that participate in the trafficking of IL-8 receptors may play an important role in the curcumin-mediated regulation. The Rab proteins Rasrelated small guanosine- $5^{\prime}$-triphosphatases (GTPases) might be essential since they are involved in the mechanisms of trafficking intracellular vesicles to the target organs [24-26]. More than 60 types of Rab proteins were found, and they play a role in regulating some of the steps involved in the intracellular trafficking of target molecules [25]. Considerable evidence showed that CXCR2 and Rab11 coexist in the recycling step of CXCR2-transfected cells $[27,28]$. These data suggested that Rab11 might be a key mediator in the distribution and trafficking pathway of IL-8 receptors upon curcumin treatment.

In this study, our data showed that curcumin treatment regulated the recycling of IL- 8 receptors and the amount of cell surface IL-8 receptors. This change may be closely associated with the anti-inflammatory response caused by the interference of the chemotactic activity of IL-8.

\section{MATERIALS AND METHODS}

\subsection{Reagents}

Curcumin was purchased from Sigma (St. Louis, Mo, USA). Polymorphprep was obtained from Axis-Shield (Oslo, Norway). IntraPrep permeabilization reagent was obtained from Immunotech (Marseille, France), rIL-8 from R\&D Systems Inc. (minneapolis, Minn, USA), Diff-Quick from Midori Juji (Osaka, Japan), Fura Red-AM from Molecular Probes (Eugene, Ore, USA). Anti-CXCR1 mouse monoclonal IgG $_{1}$ was purchased from Santa Cruz Biotechnologies (Santa Cruz, Calif, USA). Anti-CXCR2 mouse monoclonal $\mathrm{IgG}_{1}$, mouse $\mathrm{IgG}_{1}$, allophycocyanin (APC)-conjugated rat antimouse $\operatorname{IgG}_{1}$ monoclonal antibody, and purified mouse $\operatorname{IgG}_{1}$ monoclonal IgG standard were purchased from BD Pharmingen (San Diego, Calif, USA). Human IgG was purchased from Sigma. Cycloheximide was purchased from Wako Pure Chemical Industries Ltd. (Osaka, Japan).

\subsection{Neutrophil isolation}

Neutrophils were isolated from the peripheral venous blood of healthy human volunteers. Heparinized whole blood was layered onto Polymorphoprep (Axis-Shield PoC AS) and centrifuged at $500 \mathrm{xg}$ for 35 minutes. The supernatant and the peripheral blood mononuclear cell (PBMC) layers were discarded. The polymorphonuclear neutrophil (PMN) layer was removed, and hyposmotic hemolysis was performed for the remaining erythrocytes. Since $\mathrm{NH}_{4} \mathrm{Cl}$, a lysosomotrophic agent, may inhibit receptor trafficking in human neutrophils, the neutrophils used in these experiments were prepared without $\mathrm{NH}_{4} \mathrm{Cl}$. The PMNs were resuspended in RPMI 1640 medium containing $10 \%$ fetal calf serum (FCS). The purity of the neutrophil preparations was routinely found to be greater than $95 \%$ with viability greater than $98 \%$, as observed by trypan blue exclusion test.

\subsection{Curcumin treatment}

Curcumin was dissolved in dimethyl sulfoxide (DMSO) on the day of use, and was added to the cells at a final concentration of $0.5-100 \mu \mathrm{M}$. The DMSO concentration was always less than $0.1 \%$ ( $\mathrm{vol} / \mathrm{vol})$.

\subsection{Trypan blue staining}

Trypan blue solution $(0.4 \%)$ was added to the cell suspension (final concentration, $0.2 \%$ ). After treatment with curcumin $(10-100 \mu \mathrm{M})$ for 2 hours, the number of positive cells was counted in triplicate.

\subsection{Neutrophil chemotaxsis assay}

Chemotaxis was assessed by a modification of a previously described method; 24-well microchemotaxis chambers (Becton Dickinson, Cowley, UK) were used, and these were covered with polyethylene terephthalate membranes with pore size of $3 \mu \mathrm{m}[29,30]$. The lower wells were filled with $700 \mu \mathrm{L}$ of medium with various concentrations of recombinant human IL-8 (hrIL-8) $(10 \sim 10000 \mathrm{ng} / \mathrm{mL})$ or medium without hrIL-8. Subsequently, $700 \mu \mathrm{L}$ of a suspension containing $1 \times 10^{6}$ PMNs was added to each well of the upper chamber. After incubation under conditions of $90 \%$ humidity and $5 \% \mathrm{CO}_{2}$ for 1 hour at $37^{\circ} \mathrm{C}$, the cells that passed through the filter to the lower wells were stained with DiffQuick and counted in 5 high-power fields (hpf, $40 \times 10)$ using a calibrated grating. Neutrophil chemotactic activity was determined in triplicates and expressed as the average number of migrating neutrophils/5 hpf.

Next, to determine the effect of curcumin on neutrophil chemotaxis, the neutrophils were preincubated with various concentrations of curcumin $(10 \sim 100 \mu \mathrm{M})$ at $37^{\circ} \mathrm{C}$ for 2 
hours. The preincubated neutrophils were added to each well of the upper chamber and incubated for 1 hour, as described above. The cells that passed through the filter to the lower wells were stained and counted. The data obtained was expressed as described above.

\subsection{Measurement of cytosolic calcium}

The obtained neutrophils were colored yellow by curcumin that has a bimodal peak of absorption at $210 \mathrm{~nm}$ and $425 \mathrm{~nm}$. The color causes fluorescence noise when using optical instruments. To avoid interference due to the fluorescence noise, we used Fura Red because it shows decreased red fluorescence that is not interfered by curcumin. Neutrophils $\left(1 \times 10^{7}\right.$ cells $\left./ \mathrm{mL}\right)$ were loaded with $13 \mu \mathrm{M}$ Fura Red-AM in HEPES-buffered saline ( $135 \mathrm{mM} \mathrm{NaCl}, 4.6 \mathrm{mM} \mathrm{KCl}, 1.2 \mathrm{mM}$ $\mathrm{MgCl}_{2}, 11 \mathrm{mM}$ HEPES, $11 \mathrm{mM}$ glucose, $1.5 \mathrm{mM} \mathrm{CaCl}_{2}$, at $\mathrm{pH}$ 7.4) for 90 minutes at $37^{\circ} \mathrm{C}$ in a $\mathrm{CO}_{2}$ incubator. The loaded neutrophils were then analyzed using a FACS calibur system (Beckton Dickinson, USA) for analyzing red fluorescence $(640 \mathrm{~nm})$ following excitation at $488 \mathrm{~nm}$ using an argon laser. The mean channel of fluorescence was detected by CellQuest software (Beckton Dickinson) [31, 32]. The measurements of the mean channel of fluorescence can be used for statistical comparison of the cells before and after hrIL8 treatment. The data obtained showed differences between the mean channel value before and after IL-8 stimulation.

\subsection{Analysis of CXCR internalization}

Internalization analysis was performed as previously described $[8,15]$. In brief, neutrophils were preincubated with RPMI 1640 medium containing 10\% FCS supplemented with $50 \mu \mathrm{M}$ curcumin or without curcumin at $37^{\circ} \mathrm{C}$ for 2 hours. The cells were washed twice in PBS and once in bovine serum albumin medium $($ BSA medium $=$ RPMI 1640 medium containing $1 \%$ bovine serum albumin and $25 \mathrm{mM}$ HEPES). Aliquots of $5 \times 10^{6}$ cells were then removed and supplemented with $50 \mathrm{ng} / \mathrm{mL}$ hrIL-8 diluted in BSA medium, while no hrIL- 8 was added to the control tubes. The cells were incubated at $37^{\circ} \mathrm{C}$ for 2 hours and then incubated for an additional 10 minutes on ice. The cells were washed using the cell sorter buffer (CSB: PBS containing 1\% FCS, $0.02 \% \mathrm{NaN}_{3}$, and $25 \mathrm{mM}$ HEPES) and incubated at $4^{\circ} \mathrm{C}$ for 15 minutes with human IgG to block the Fc receptors. They were washed twice with CSB and incubated with either monoclonal mouse anti-CXCR1 or anti-CXCR2 antibody and mouse-IgGla as the control. Following the 15-minute incubation, the cells were washed twice in CSB, and APCconjugated rat antimouse IgG antibody was added and incubated at $4^{\circ} \mathrm{C}$ for 15 minutes. Since APC emission is collected in a detector for fluorescence wavelengths between $640 \mathrm{~nm}$ and $680 \mathrm{~nm}$, in these experiments, interference by curcumin fluorescence should be avoided.

The cells were then washed once in CSB and resuspended in PBS containing $0.02 \% \mathrm{NaN}_{3}$. Flow cytometry was performed using the FACS calibur system. It was used to analyze 10000 live cell events.

\subsection{Staining of both cell surface and intracytoplasmic CXCR}

The neutrophils were permeabilized using the IntraPrep permeabilization reagent, including reagents 1 and 2, according to the manufacturer's instructions [33]. In brief, to stain CXCR present on the surface of the cell membrane, the neutrophils were incubated with a primary antibody at $4{ }^{\circ} \mathrm{C}$ for 15 minutes, washed twice with CSB, and stained with the secondary antibody for 15 minutes. Following incubation, $100 \mu \mathrm{L}$ of IntraPrep reagent 1 was added for fixation. After vigorous vortexing, the cells were incubated for 15 minutes at room temperature. After one wash with PBS, $100 \mu \mathrm{L}$ of IntraPrep reagent 2 was added, and then the mixture was incubated for 5 minutes at room temperature for permeabilization. Next, the neutrophils were incubated with the primary antibody at $4^{\circ} \mathrm{C}$ for 15 minutes, and the intracellular IL-8 receptors were incubated with the secondary antibody for 15 minutes. Following these incubations, the cells were washed once with CSB and resuspended in PBS containing $1 \%$ formaldehyde. Subsequently, flow cytometry analysis was performed.

\subsection{Western blotting}

The pretreated neutrophils were lysed in a "lysis buffer" comprising $50 \mathrm{mM}$ HEPES (pH 7.4), $150 \mathrm{mM} \mathrm{NaCl}, 1 \mathrm{mM}$ EDTA, $1 \%$ Triton X-100, 10\% Glycerol, $1 \mathrm{mM} \mathrm{NaF}, 2 \mathrm{mM}$ Na orthovandate, $0.1 \mathrm{nM}$ phenylmethylsulfonyl fluoride, $5 \mu \mathrm{g} / \mathrm{mL}$ leupeptin, $4.6 \mu \mathrm{g} / \mathrm{mL}$ aprotinin, and $3.5 \mathrm{ng} / \mathrm{mL}$ Pepstatin A. Proteins in the cell lysates were separated by sodium dodecyl sulfate-polyacrylamide gel electrophoresis (SDS-PAGE) under reducing conditions and then blotted onto nitrocellulose membranes (Hybond $\mathrm{C}^{+}$, Amersham Pharmacia Biotech, UK). The membranes were blocked in NET buffer $(50 \mathrm{mM}$ Tris- $\mathrm{HCl}, \mathrm{pH}$ 7.5, $150 \mathrm{mM} \mathrm{NaCl}, 5 \mathrm{mM}$ EDTA, 0.05\% Triton $\mathrm{X}-100)$ containing $1 \%$ gelatin and then incubated sequentially with the respective antibodies and rabbit or mouse IgG TrueBlot (eBioscience, San Diego, Calif, USA). The protein bands were visualized with an enhanced chemiluminescence (ECL) detection kit (Amersham Pharmacia Biotech).

\subsection{Immunoprecipitation analysis}

The neutrophil lysate was obtained as described above. The lysates were precleared by incubation for 1 hour with TrueBlot antimouse Ig IP beads (eBioscience). The primary antibody and TrueBlot antimouse Ig IP beads were added to the precleared lysates. The beads were washed in a washing buffer [50 mM HEPES (pH 7.4), $150 \mathrm{mM} \mathrm{NaCl}, 0.1 \%$ Triton X-100, $10 \%$ Glycerol] and resuspended in the SDS sample buffer. Immunoprecipitation and western blotting were performed as described above.

\subsection{Determination of $I L-8$ receptors recycling on the cell surface}

The procedure used to determine receptor recycling was similar to that used to determine receptor internalization. The 
samples were allowed to undergo a receptor recovery process that was performed as previously described [17]. In brief, internalization was induced by exposure to $1000 \mathrm{ng} / \mathrm{mL}$ hrIL8 for 30 minutes at $37^{\circ} \mathrm{C}$. In order to allow receptor recovery, the cells were washed once and resuspended in BSA medium at $37^{\circ} \mathrm{C}$ for the specified time periods. The neutrophils were incubated with the specified concentrations of curcumin during the IL- 8 receptor recovery process. To reduce the contribution of de novo protein synthesis to receptor reappearance on the cell membrane, cell samples undergoing receptor recovery were incubated with medium containing $10 \mu \mathrm{g} / \mathrm{mL}$ cycloheximide. Following incubation, the cells were washed and labeled at $4^{\circ} \mathrm{C}$ with anti-CXCR 1 or anti-CXCR2 antibody and mouse IgG, as described above. The FACS calibur system was used to analyze 10000 live cell events.

\subsection{Statistical analysis}

Data are expressed as mean values \pm standard error. Statistical significance was determined by Student $t$ tests and correlation coefficients. A $P$ value less than .05 was considered significant.

\section{RESULTS}

\subsection{Effect of curcumin on neutrophil chemotactic activity}

Chemotaxis was assessed using microchemotaxis chambers covered with polyethylene terephthalate membranes. We observed that neutrophils rapidly passed through the membranes toward the wells of the lower chamber containing hrIL-8. After 1 hour of incubation, the neutrophils that passed through the filter to the lower wells were counted. In Figures 1(a) and 1(b) triplicate results of the average number of migrating neutrophils/5 hpf are shown. These data revealed that the chemotactic activity of neutrophils was stimulated by hrIL- 8 in a dose-dependent manner.

To determine the effect of curcumin on neutrophil chemotaxis, the neutrophils were incubated with various concentrations of curcumin added to the wells of the upper chamber. As shown in Figures 1(c) and 1(d), curcumin significantly inhibited cell migration induced by hrIL$8(10000 \mathrm{pg} / \mathrm{mL})$ at concentrations of $10-100 \mu \mathrm{M}$ in a dosedependent manner.

The obtained neutrophils were cultured in the presence of various doses of curcumin for 2 hours. The viability of neutrophils was examined using trypan blue staining. Curcumin did not affect neutrophil viability at a concentration up to $100 \mu \mathrm{M}$ when compared with the control treatment (data not shown). In these experiments, agonist stimulation at $37^{\circ} \mathrm{C}$ did not cause a significant decrease in the cell number or reduction in cell viability ( $>99 \%$ by trypan blue exclusion).

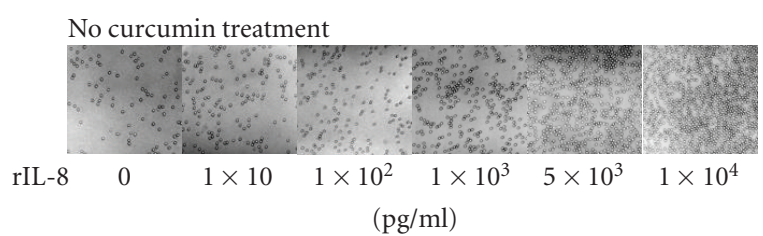

(a)

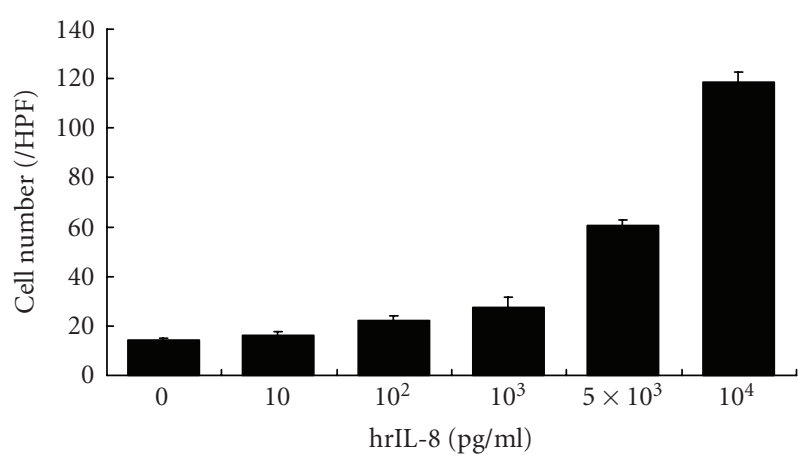

(b)

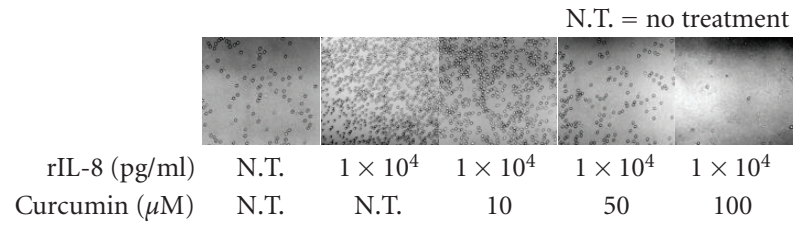

(c)

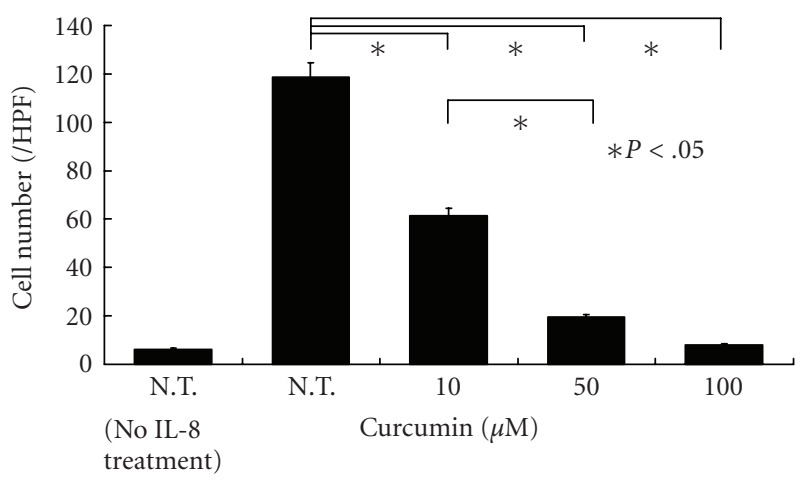

(d)

FIGURE 1: The effect of curcumin on the chemotactic activity in human neutrophils. Chemotaxis was assessed by using 24-well microchemotaxis chambers covered with membranes ( $3 \mu \mathrm{m}$ pore size). The lower wells were filled with a medium containing various concentrations of hrIL-8, and $1 \times 10^{6}$ PMNs were then added to each well of the upper chamber. (a) The neutrophils that passed through the filter were counted. (b) hrIL-8 induced neutrophil chemotaxis in a dose-dependent manner. Next, the neutrophils were preincubated with various concentrations of curcumin for 2 hours at $37^{\circ} \mathrm{C}$. Preincubated neutrophils were added to each well of the upper chamber, and the chemotaxis activity was assessed as described above. (c) Cells were counted after curcumin treatment. (d) Curcumin significantly inhibited the chemotactic activity induced by hrIL- 8 at concentrations of $10-100 \mu \mathrm{M}$ in a dose-dependent manner. The neutrophil chemotactic activity determined in triplicate was expressed as the average number of migrating neutrophils/5 hpf. Each bar represents the mean \pm SE of three individual experiments. Statistical significance versus the control: $* P<.05$. 


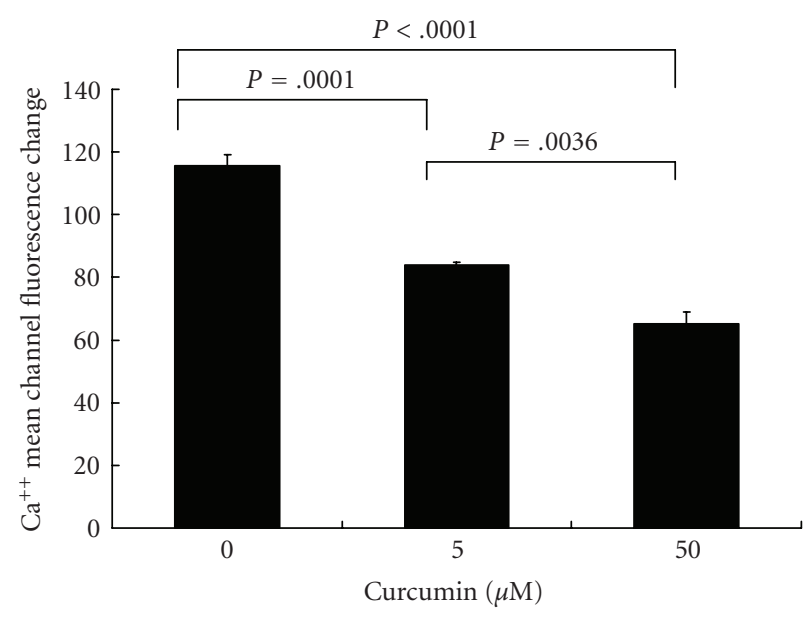

FIGURE 2: Curcumin blocks the hrIL-8-induced intracellular $\mathrm{Ca}^{2+}$ enhancement. Neutrophils $\left(1 \times 10^{6}\right.$ cells $\left./ \mathrm{mL}\right)$ treated with various concentrations of curcumin for 2 hours were loaded with $13 \mu \mathrm{M}$ Fura Red-AM in HEPES-buffered saline for 90 minutes at $37^{\circ} \mathrm{C}$ in a $\mathrm{CO}_{2}$ incubator. Addition of hrIL-8 $(50 \mathrm{ng} / \mathrm{mL})$ increased the intracellular calcium concentration and caused a decrease in the Fura Red fluorescence. The change in the fluorescence intensity at $640 \mathrm{~nm}$ was analyzed on an FACS calibur system. The mean channel of the fluorescence was analyzed by CellQuest software. The data obtained showed differences between the mean channel value before and after hrIL-8 stimulation. Curcumin significantly inhibited the increase in the intracellular calcium concentrations in a dose-dependent manner. Data was obtained from three independent experiments and was represented.

\subsection{Curcumin inhibits the increase in the intracellular calcium concentration}

To determine the effect of curcumin on intracellular signaling due to IL-8-mediated IL-8 receptor stimulation, we investigated the effects of changes in the intracellular calcium concentration.

Approximately $1 \times 10^{6}$ neutrophils treated with various concentrations of curcumin for 2 hours were loaded in a volume of $100 \mu \mathrm{L}$ in culture tubes containing $13 \mu \mathrm{M}$ Fura Red-AM in HEPES-buffered saline $(135 \mathrm{mM} \mathrm{NaCl}, 4.6 \mathrm{mM}$ $\mathrm{KCl}, 1.2 \mathrm{mM} \mathrm{MgCl}_{2}, 11 \mathrm{mM}$ HEPES, $11 \mathrm{mM}$ glucose, $1.5 \mathrm{mM}$ $\mathrm{CaCl}_{2}$ at $\mathrm{pH}$ 7.4) for 90 minutes at $37^{\circ} \mathrm{C}$ in a $\mathrm{CO}_{2}$ incubator. As shown in Figure 2, hrIL-8 $(50 \mathrm{ng} / \mathrm{mL})$ increased the intracellular calcium concentration, and this phenomenon was demonstrated as a decrease in the Fura Red fluorescence. Curcumin significantly inhibited the increase in the intracellular calcium concentrations in a dose-dependent manner. These data suggested that curcumin reduced neutrophil chemotaxis by affecting signal transduction mediated by IL- 8 via the IL-8 receptors.

\subsection{Curcumin promotes the downregulation of the expression of IL-8 receptors on the neutrophil surface}

To investigate the status of IL-8 receptors after curcumin treatment, we examined the IL- 8 receptor on the cell surface by FACScan using the CXCR1 and CXCR2 monoclonal antibodies.

As shown in Figure 3, both CXCR1 and CXCR2 present on the cell surface were downregulated by hrIL-8 $(50 \mathrm{ng} / \mathrm{mL})$ treatment due to receptor internalization. In addition, both IL-8 receptors present on the surface of neutrophils treated with curcumin were downregulated by rIL-8 $(50 \mathrm{ng} / \mathrm{mL})$ to a greater extent. These data revealed that the amounts of intracellular CXCR1 and CXCR2 are relatively increased by curcumin treatment. These findings indicated that the regulation of neutrophil chemotaxis may depend on the decreased amounts of CXCR1 and CXCR2 present on the cell surface.

\subsection{Regulation of CXCR1 and CXCR2 by curcumin without de novo protein synthesis}

To determine whether the production of IL- 8 receptors in neutrophils has influenced the curcumin treatment, we also evaluated the change of IL-8 receptors without de novo synthesis which are transported to the cell surface.

Neutrophils were incubated with cycloheximide, a strong protein synthesis inhibitor, at a concentration of $10 \mathrm{ng} / \mathrm{mL}$. FACScan analysis showed the same decrease pattern of the amount of IL-8 receptor present on the cell surface. Cycloheximide treatment did not alter the reduction of IL-8 receptors after hrIL-8 treatment in curcumin-treated neutrophils (see Figure 4). These findings suggested that de novo synthesis of IL-8 receptors may not be associated with the changes due to curcumin treatment of IL- 8 receptors present on the cell surface.

\subsection{Effect of curcumin on the distribution of IL-8 receptors}

To investigate the influence of curcumin on the degradation of IL-8 receptors, we determined the total cellular amount of IL-8 receptors by flow cytometry.

The expression of total cellular amount of IL-8 receptors revealed no significant difference between the curcumintreated and the control neutrophils (see Figure 5). However, in the curcumin-treated neutrophils, the IL- 8 receptors on the cell surface showed obviously decrease than the control (see Figures 3(e) and 3(f)).

Taken together, these data suggested that curcumin changes the cellular distribution of IL-8 receptors. The increment of the intercellular IL-8 receptors may account for the decrement of IL-8 receptors on the cell surface after curcumin treatment.

\subsection{Curcumin blocks CXCR recycling}

In order to investigate the impact on the recycling pathway, the obtained neutrophils were pretreated with hrIL-8 $(1000 \mathrm{ng} / \mathrm{mL})$ at $37^{\circ} \mathrm{C}$ for 30 minutes. They were resuspended for the specified time periods in hrIL-8-free medium containing various concentrations of curcumin. Representative data of CXCR1 recycling for 30 minutes and CXCR2 recycling for 120 minutes are shown in Figure 6. The recycling 


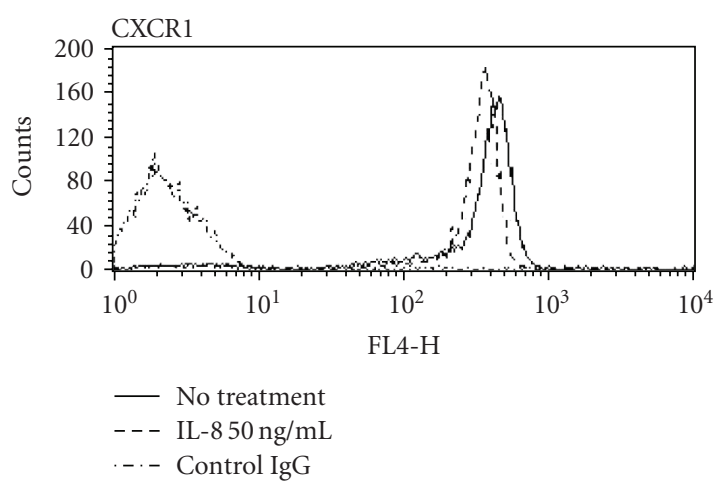

(a)

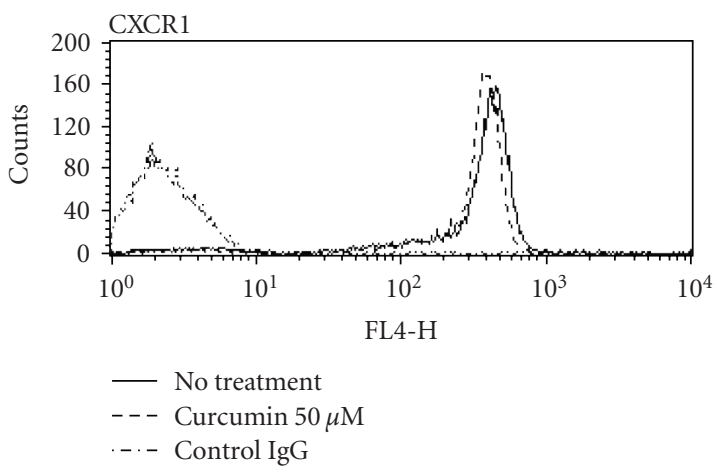

(c)

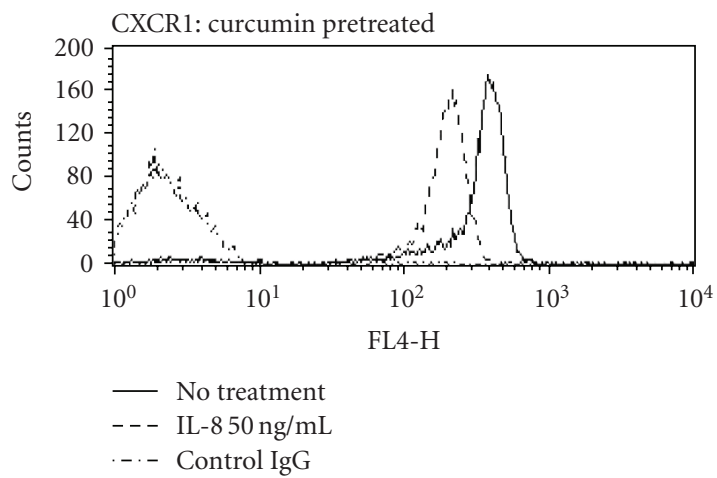

(e)

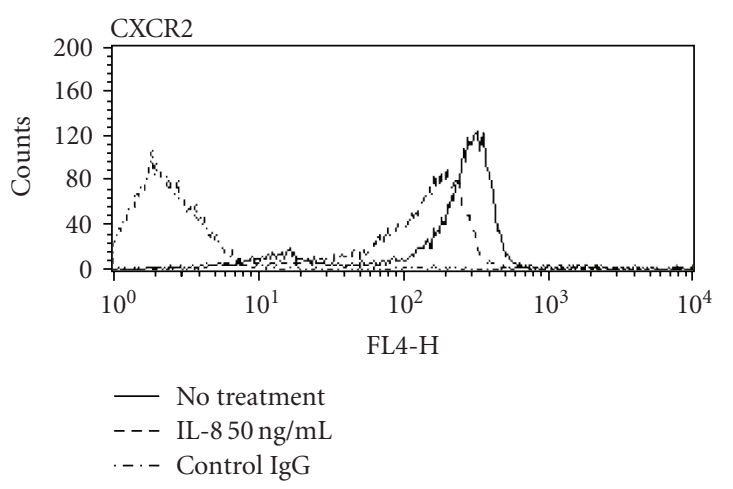

(b)

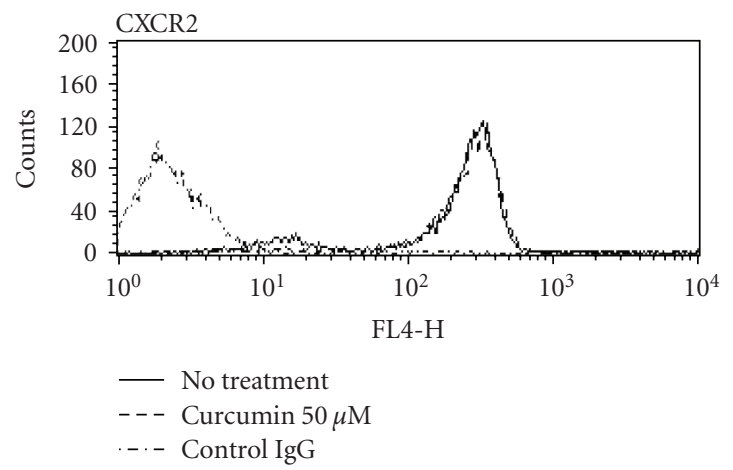

(d)

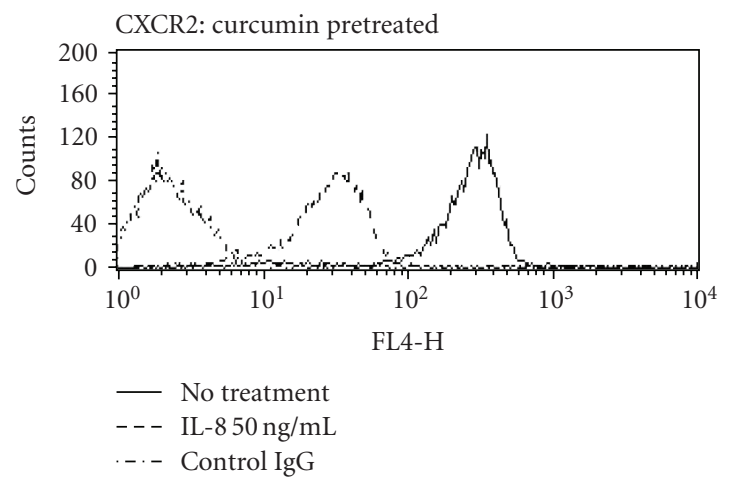

(f)

FIGURE 3: Effect of curcumin on the internalization of the IL-8 receptor. The obtained neutrophils were preincubated in medium with or without $50 \mu \mathrm{M}$ curcumin at $37^{\circ} \mathrm{C}$ for 2 hours. They were washed and incubated at $37^{\circ} \mathrm{C}$ for 2 hours with $50 \mathrm{ng} / \mathrm{mL}$ hrIL- 8 diluted in BSA medium, while no hrIL- 8 was added to the control tubes. The expressions of CXCR1 and CXCR2 present on the cell surface were determined with anti-CXCR1 ((a), (c), (e)) or anti-CXCR2 ((b), (d), (f)) mouse monoclonal antibodies by measuring the content of APC-conjugated antimouse IgG antibody using flow cytometry. CXCR1 (a) and CXCR2 (b) present on the surface of the untreated neutrophils were decreased by internalization after hrIL-8 $(50 \mathrm{ng} / \mathrm{mL})$ exposure. The amount of CXCR1 present on the cell surface slightly decreased after curcumin treatment (c), while that of CXCR2 shows a very slight change (d). A more dynamic decrease in the amount of CXCR1 (e) and CXCR2 (f) was observed in curcumin-treated neutrophils than in the untreated neutrophils after hrIL- 8 treatment. Shown are representatives of three independent experiments with similar results.

of CXCR1 and CXCR2 to the cell membrane was blocked by curcumin in a dose-dependent manner (see Figure 6).

\subsection{Rab11 interaction with CXCR}

In order to assess the interaction of the small GTPase Rab11 that functionally regulates cytosolic trafficking of IL-8 re- ceptors in human primary neutrophils, we analyzed antiCXCR1 and anti-CXCR2 immunoprecipitates for the presence of Rab11.

Western blotting showed that the total amount of the Rab11 protein was not altered by curcumin treatment (see Figure 7(a)). Immunoprecipitation studies were performed to determine the association of CXCR1 and CXCR2 with 


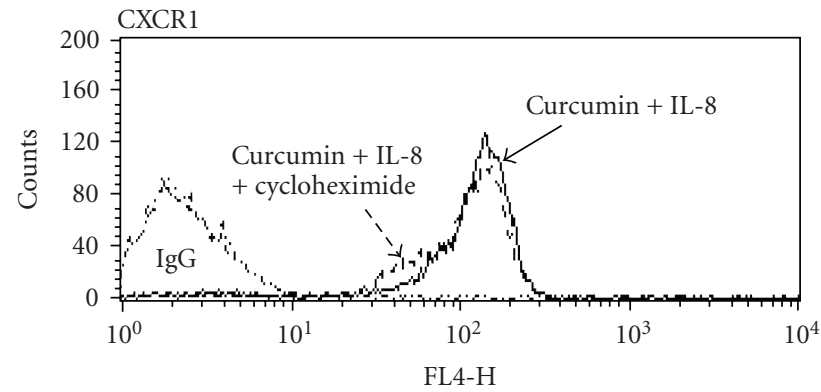

(a)

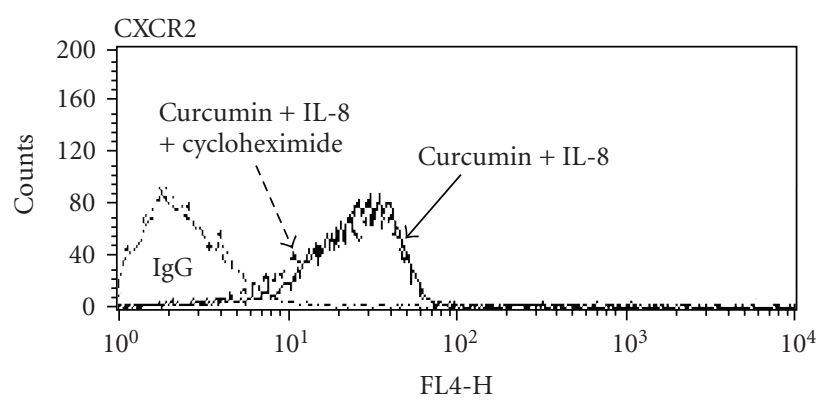

(b)

FIGURE 4: Effect of curcumin on the reduction of the IL-8 receptors without protein synthesis. After preincubation of neutrophils with curcumin $(50 \mu \mathrm{M})$ for 2 hours, they were incubated with hrIL-8 $(50 \mathrm{ng} / \mathrm{mL})$ for 30 minutes. While the neutrophils were incubating, cycloheximide $(10 \mu \mathrm{g} / \mathrm{mL})$ was added to determine whether the de novo synthesis has any effect on the reduction of IL-8R by curcumin. The same decrease pattern of the amount of IL-8 receptor present on the cell surface was observed with cycloheximide. The inhibition of protein synthesis did not alter the reduction of both CXCR1 and CXCR2 by curcumin treatment. Shown are representatives of three independent experiments with similar results.
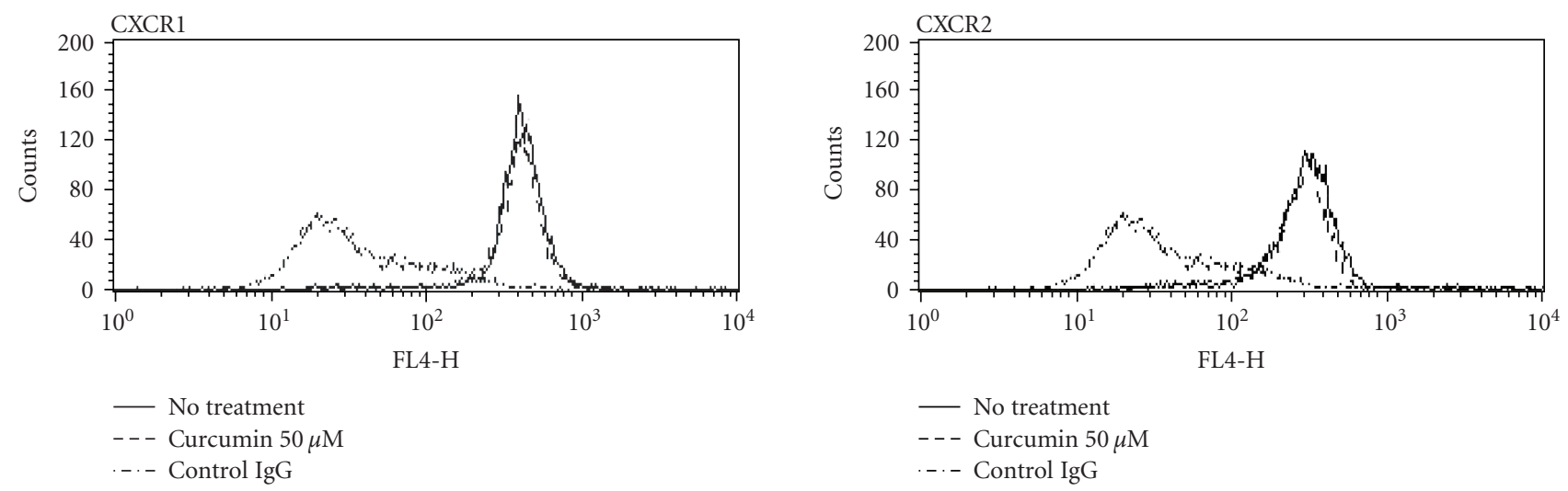

(a)
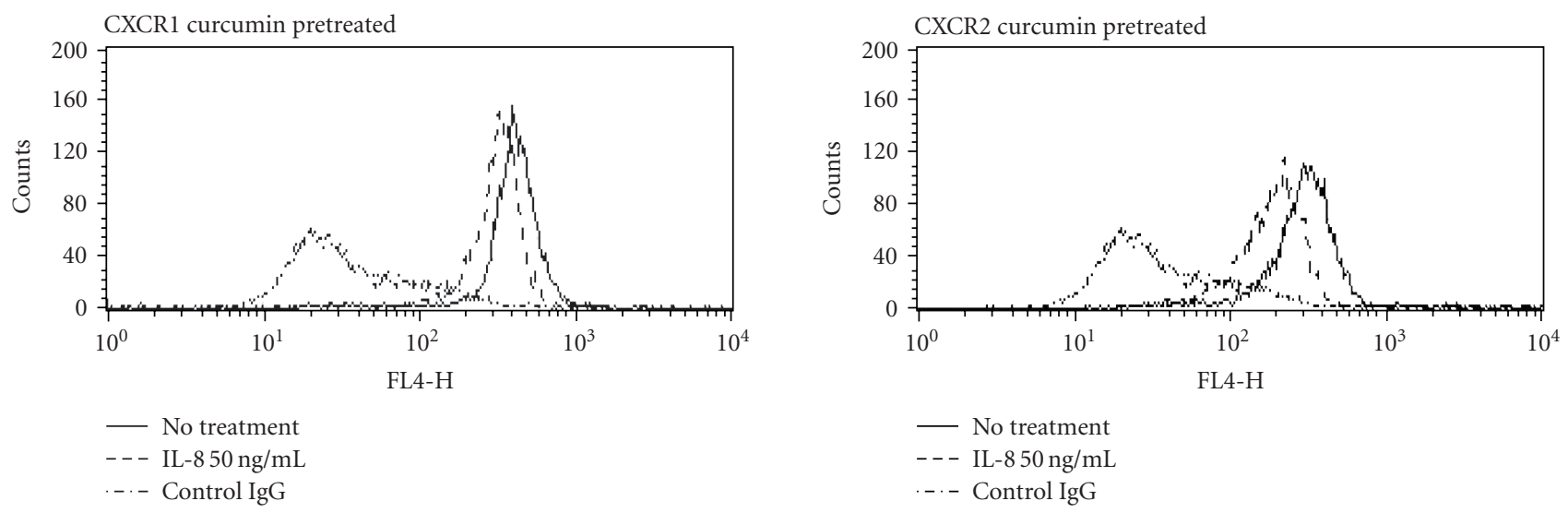

(b)

FIGURE 5: The impact of curcumin on the total amount of IL-8 receptors. Both IL-8 receptors on the cell surface and in the cytosol were stained using the permeabilization technique. The total cellular amount of the receptors was determined by flow cytometry. (a) The expression of total IL-8 receptors revealed no significant difference between curcumin-treated and untreated neutrophils. (b) Furthermore, in case of the curcumin-treated neutrophils, the total amount of IL- 8 receptors showed a smaller decrease after IL- 8 treatment than that shown by the receptors on the cell surface of curcumin-treated neutrophils (see Figures 3(e) and 3(f)). 


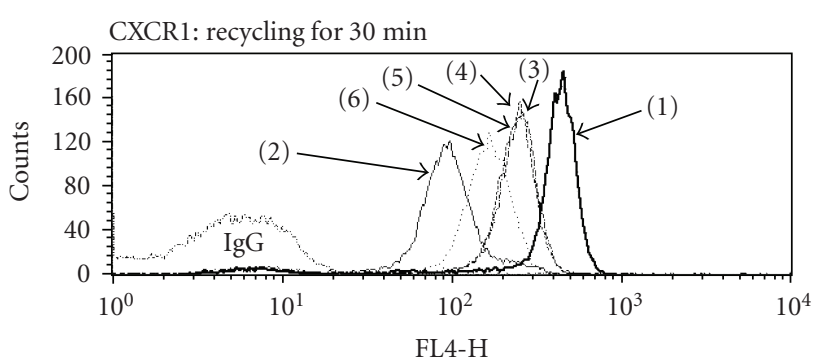

(a)

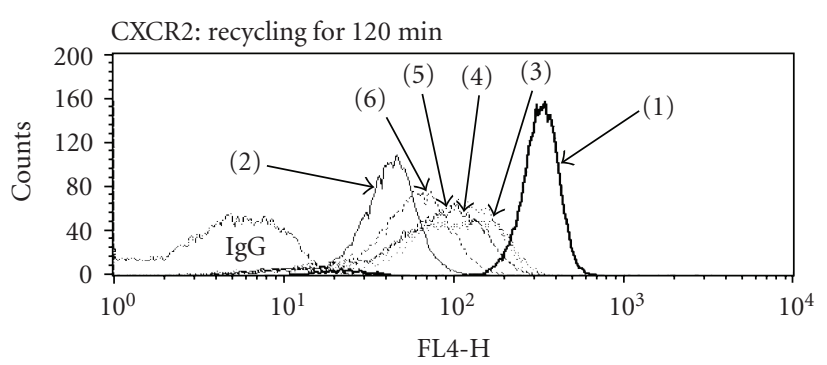

(b)

Figure 6: Curcumin blocks the recovery process of IL-8 receptors. The effect of curcumin on the recycling of IL- 8 receptors to the surface of neutrophils was examined by FACScan. Internalization was induced by 30 -minute exposure to $1000 \mathrm{ng} / \mathrm{mL}$ hrIL- 8 at $37^{\circ} \mathrm{C}$. In order to facilitate receptor recovery, the cells were washed once and resuspended in BSA medium containing $10 \mu \mathrm{g} / \mathrm{mL}$ cycloheximide with various concentrations of curcumin at $37^{\circ} \mathrm{C}$ for the specified time periods. Following incubation, the cells were labeled as described above. (a) The cells were treated under the following conditions: (1) untreated cells; (2) cells treated with hrIL-8 and no recovery; (3) cells treated with hrIL-8 and recovery for 30 minutes; (4) cells treated with hrIL- 8 and recovery for 30 minutes with curcumin $(0.5 \mu \mathrm{M})$; (5) cells treated with hrIL-8 and recovery for 30 minutes with curcumin $(5 \mu \mathrm{M})$; and (6) cells treated with hrIL-8 and recovery for 30 minutes with curcumin $(50 \mu \mathrm{M})$. (b) The cells were treated under the following conditions: (1) untreated cells; (2) cells treated with hrIL-8 and no recovery; (3) cells treated with hrIL8 and recovery for 120 minutes; (4) cells treated with hrIL- 8 and recovery for 120 minutes with curcumin $(0.5 \mu \mathrm{M})$; (5) cells treated with hrIL- 8 and recovery for 120 minutes with curcumin $(5 \mu \mathrm{M})$; and (6) cells treated with hrIL-8 and recovery for 120 minutes with curcumin $(50 \mu \mathrm{M})$. Curcumin treatment blocked the recycling of CXCR1 (a) and CXCR2 (b) to the cell surface of the human primary neutrophils in a dose-dependent manner. Representative data is shown. Shown are representatives of three independent experiments with similar results.

Rab11 after curcumin treatment. Both receptors showed interaction with Rab11 (see Figures 7(b), 7(c), and 7(d)). These associations in both receptors were enhanced after curcumin treatment.

\section{DISCUSSION}

Various inflammations cause biological responses such as neutrophil activation through proinflammatory cytokine receptors; however, the mechanisms that control these cy- (a) WB: Rab11
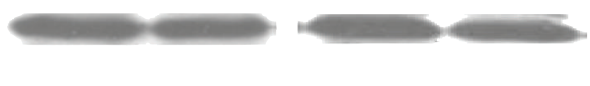

Curcumin

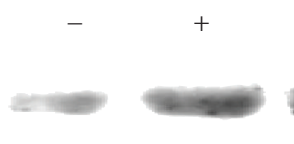

$+$

(b) IP: CXCR1 WB: Rab11

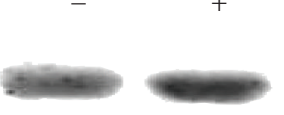

(c) IP: CXCR2 WB: Rab11
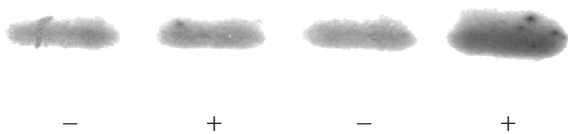

Curcumin

Pre IL-8 stimulation

Post IL-8 stimulation

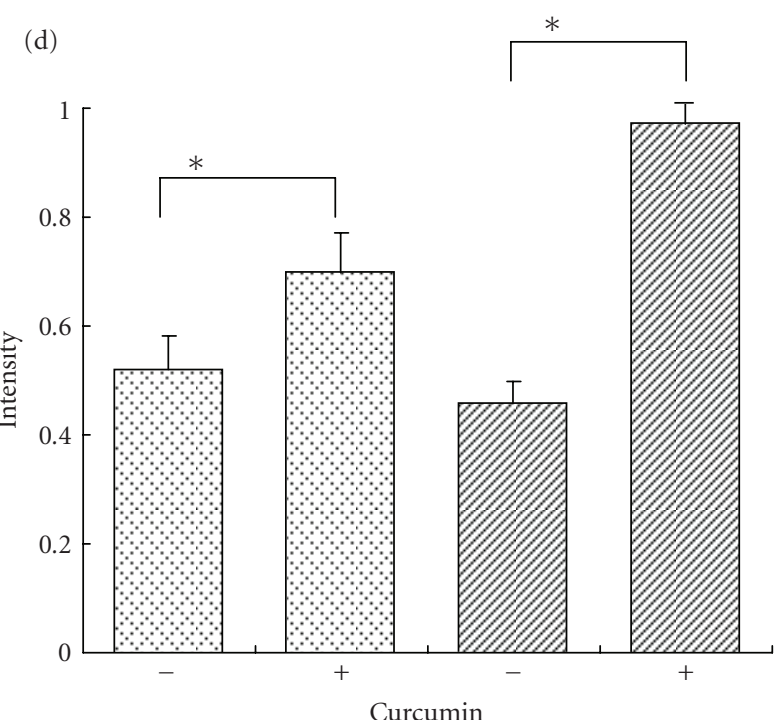

CXCR1
C CXCR2
$* \quad P<.001$

Figure 7: Rab-11 interaction with CXCR. (a) Proteins in the neutrophil lysates were separated by SDS-PAGE followed by blotting onto nitrocellulose membranes. The protein bands were detected by western blotting as described above. The amount of Rab11 protein was not remarkably different in curcumin-treated and untreated neutrophils. We analyzed anti-CXCR1 and CXCR2 immunoprecipitates for the presence of Rab-11. In primary neutrophils, analysis of the immunoprecipitates with anti-CXCR1 and anti-CXCR2 monoclonal antibodies supported the existence of an association with Rab-11. (b) Coimmunoprecipitation of Rab11 with CXCR1 revealed an increase after curcumin treatment. (c) After hrIL-8 exposure, coimmunoprecipitation of Rab11 with CXCR2 was enhanced though the association of Rab11 with CXCR2 not really appearing to be enhanced after curcumin treatment without IL-8 treatment. (d) In particular, curcumin-treated neutrophil showed remarkable increase ratio compared to the untreated neutrophil after IL- 8 stimulation. Representative of three separate experiments are shown. The results of immunoprecipitates are expressed as an intensity ratio of the densitometry units relative to the amount of the basal Rab11 . Results are presented as the mean \pm SD from three experiments.

tokine receptors remain unclear. In this study, we reported that the chemotaxis of primary cultured human neutrophils 
was significantly inhibited in a dose-dependent manner by curcumin treatment. This inhibition did not result from curcumin-induced cell cytotoxicity, since the total number of cells and the cell viability at the end of the culture period did not differ with the culture conditions. Antichemotaxis provided important evidence for the anti-inflammatory responses due to curcumin treatment because neutrophil accumulation is a primary response in local inflammation, and this is followed by activation and infiltration of neutrophils.

Numerous chemokines play a crucial role in these biological responses. In particular, IL- 8 is a strong neutrophil chemoattractant in the local inflammatory site. Other researchers, including our group, have already reported that curcumin inhibits the production of IL- 8 by monocytes, macrophages, and other lymphatic cells [8]. The blockage of IL- 8 production should be one of the key factors in the regulation of inflammation caused by neutrophils. Another way in which the inflammation elicited by neutrophils can be inhibited is by the interception of IL- 8 promoted signal transduction in neutrophils.

In this study, neutrophils chemotaxis via hrIL-8 was significantly inhibited by curcumin. Experimental studies have demonstrated that human anti-CXCR monoclonal antibodies blocked IL-8-dependent cellular functions including neutrophil chemotaxis directly [34]. Our previous study reported that exogenous IL-8 could not recover response to IL8 receptor by curcumin treatment [8]. Therefore, we examined about IL-8 signal transduction through IL-8 receptors after curcumin treatment.

In our study, a $\mathrm{Ca}^{2+}$ mobilization assay confirmed that IL- 8 signal transduction through IL- 8 receptors was blocked by curcumin treatment. Regarding the mechanisms of IL- 8 receptor signaling, it is widely accepted that ligand-promoted internalization is one of the most important initiating pathways $[19,21,22,35]$. In neutrophils, IL-8 stimulated the $\beta$-arrestin-dependent internalization of the CXCR receptor $[19,36]$. Upon agonist binding, CXCR1 and CXCR2 receptor activation is followed by receptor phosphorylation at multiple serine residues and subsequent desensitization of the receptor to further stimulation $[17,21,37]$. These events are usually accompanied by receptor endocytosis and/or recycling of the receptor.

In our study, FACScan analysis showed a decrease in the amount of both CXCR1 and CXCR2 present on the cell surface after curcumin treatment. In particular, after IL-8 promoted receptor internalization, the amount of IL- 8 receptors on the neutrophil cell surface is significantly decreased. Curcumin has been shown to inhibit NF-kB activity and to block a signal upstream of the NF-kB-inducing kinase and IKK and curcumin is suggested to regulate some transcriptional factors [9]. After blocking new protein synthesis by cycloheximide, our experiments showed the same decrease pattern in the IL- 8 receptors present on the cell surface. This result suggests that the decrease in the amount of IL- 8 receptors present on the cell membrane was not only due to degradation. The possibility of the receptor shedding should be considered, but there is no convincible report concern- ing the shedding of IL-8R. Moreover, Figure 5 demonstrated that the total amount of CXCR is not different after curcumin treatment, we consider that the possibility of the receptor shedding is deniable. This finding was consistent with those of our previous studies, suggesting that curcumin may affect the ligand-promoted trafficking pathway of the IL- 8 receptor [8].

The trafficking pathway of IL-8 receptors is known to comprise two different transport directions including internalization and externalization. Either promotion of internalization or inhibition of externalization should induce a decrease in the amount of receptors present on the cell surface. Our experiments based on FACScan confirmed that curcumin delayed the trafficking pathway in the cytosol, and this resulted in the blockage of the recycling pathway to the cell surface. The Rab GTPase family is known to play an essential role in the cellular trafficking pathway. In particular, Rab11 is associated with the recycling compartment and trans-Golgi network (TGN) membranes, and it controls the slow endosomal recycling pathway as well as the traffic from the TGN $[24,26,38]$. The small GTPase Rab11 has been reported to regulate the trafficking of CXCR2 through the recycling endosome $[27,28]$. Our immunoprecipitation study also showed the association of CXCR2 and Rab11 in primary neutrophils. Moreover, an association between CXCR1 and Rab11 was indicated. Further analyses are required to determine the mechanism of blockage of IL- 8 receptor recycling; however, this is the first report on the association of the IL-8 receptor with Rab11 in primary cultured neutrophils. Following curcumin treatment, the binding of Rab11 and CXCR1 and CXCR2 appeared to be more prominent. The recycling process from the endosome to the cell surface remains unclear; however, stacking of the receptor proteins with the transporter proteins may be responsible for the deposition of IL- 8 receptors in the endosomes. Therefore, it can be considered that these findings are consistent with those of previous studies that showed a reduction in the recycling of IL-8 receptors. Although our study had several limitations, these data suggest that curcumin might induce the stacking of the Rab11 vesicle complex with CXCR1 and CXCR2 in the endocytic pathway.

Moreover, curcumin is suggested to affect signal transduction from the other transmembrane receptors, such as transferrin receptor and the $\mathrm{m} 4$ muscarinic acetylcholine receptor, whose recycling is regulated by Rab11 through cytosolic trafficking pathways [39]. Since curcumin is also known to be an inhibitory factor for several serine/threonine kinases, such as PKC [40] and IKK [9], GTPases activity might be inhibited by kinase dephosphorylation, and this could result in an increased stability of the transporter protein association. Although phosphorylation is a crucial determinant of IL-8 receptor internalization, our western blotting data showed no significant difference in the mobility of the IL- 8 receptor due to phosphorylation (data not shown). Previous studies were unable to completely explain the delays in CXCR1 and CXCR2 recycling to the cell surface by curcumin; however, it is possible that curcumin has an effect on the transport system due to 
recycling of the endosomes because the association of the IL-8 receptor with Rab11 after curcumin treatment was increased.

Recent studies suggested that curcumin has various mechanisms for bioactivity. These findings have identified curcumin as a regulator of kinase activities, a regulator of transcriptions, and a modulator of oxidative agent. Although there is no evidence about direct interact with membranous receptor, some investigators suggested that curcumin have a unique role in a modification of membranous or cytoskeleton system [41]. Previous study cannot fully explain about mechanisms of regulation of IL-8 receptor by curcumin, but our result is partially consistent with those of prior studies showing modification of cytosol components by curcumin [42].

As for our studies' limitation, we would have included an inactive analog in our study, if one had been available. There are several analogs and metabolites which have been reported [43], but almost analogs have a similar and modified effect of curcumin, which are not useful as an inactive control in this study.

In conclusion, our data provide some noteworthy evidence that curcumin inhibits neutrophil chemotactic activity caused by IL- 8 chemokine. Curcumin is suggested to inhibit CXCR1 and CXCR2 recycling; this results in a decrease in neutrophil chemotaxis. In addition, we demonstrated that curcumin treatment changed the intercellular trafficking of the IL-8 receptor in neutrophils. These mechanisms may involve inhibition of the endosomal transport pathway by members of the Rab11 family.

Our study suggests that curcumin affects numerous bioactivities that involve signal transduction through the IL8 receptor. Therefore, curcumin is able to function as a potent anti-inflammatory agent that regulates the receptor trafficking pathway in cytosol. In vivo use of curcumin might be beneficial for patients with inflammation due to the enhanced production of various proinflammatory cytokines, such as ARDS and pancreatitis as well as patients with the paraneoplastic syndrome. Recently a great deal of evidence has revealed that cytokine overreaction contributes to the severity of the systemic inflammation response syndrome (SIRS) [44]. Therefore, the control of cytokine signal transduction may play an important role in the inflammation therapy.

The unique mechanisms by which curcumin regulates the receptor transport system should be further elucidated.

\section{REFERENCES}

[1] O. P. Sharma, "Antioxidant activity of curcumin and related compounds," Biochemical Pharmacology, vol. 25, no. 15, pp. 1811-1812, 1976.

[2] K. K. Soudamini and R. Kuttan, "Inhibition of chemical carcinogenesis by curcumin," Journal of Ethnopharmacology, vol. 27, no. 1-2, pp. 227-233, 1989.

[3] J. C. Baumann, "Effect of chelidonium, curcuma, absinth and Carduus marianus on the bile and pancreatic secretion in liver diseases," Medizinische Monatsschrift, vol. 29, no. 4, pp. 173180, 1975.
[4] Y. X. Xu, K. R. Pindolia, N. Janakiraman, C. J. Noth, R. A. Chapman, and S. C. Gautam, "Curcumin, a compound with anti-inflammatory and anti oxidant properties, downregulates chemokine expression in bone marrow stromal cells," Experimental Hematology, vol. 25, no. 5, pp. 413-422, 1997.

[5] J. Miquel, A. Bernd, J. Sempere, J. Díaz-Alperi, and A. Ramírez, "The curcuma antioxidants: pharmacological effects and prospects for future clinical use. A review," Archives of Gerontology and Geriatrics, vol. 34, no. 1, pp. 37-46, 2002.

[6] M.-S. Woo, S.-H. Jung, S.-Y. Kim, et al., "Curcumin suppresses phorbol ester-induced matrix metalloproteinase- 9 expression by inhibiting the PKC to MAPK signaling pathways in human astroglioma cells," Biochemical and Biophysical Research Communications, vol. 335, no. 4, pp. 1017-1025, 2005.

[7] Y.-R. Chen and T.-H. Tan, "Inhibition of the c-Jun N-terminal kinase (JNK) signaling pathway by curcumin," Oncogene, vol. 17, no. 2, pp. 173-178, 1998.

[8] H. Hidaka, T. Ishiko, T. Furuhashi, et al., "Curcumin inhibits interleukin 8 production and enhances interleukin 8 receptor expression on the cell surface: impact on human pancreatic carcinoma cell growth by autocrine regulation," Cancer, vol. 95, no. 6, pp. 1206-1214, 2002.

[9] C. Jobin, C. A. Bradham, M. P. Russo, et al., "Curcumin blocks cytokine-mediated NF- $\kappa$ B activation and proinflammatory gene expression by inhibiting inhibitory factor I- $\kappa \mathrm{B}$ kinase activity," Journal of Immunology, vol. 163, no. 6, pp. 34743483, 1999.

[10] S. Singh and B. B. Aggarwal, "Activation of transcription factor NF- $\kappa$ B is suppressed by curcumin (diferulolylmethane)," Journal of Biological Chemistry, vol. 270, no. 42, pp. 24995-25000, 1995.

[11] B. Y. Kang, S. W. Chung, W.-J. Chung, S.-Y. Im, S. Y. Hwang, and T. S. Kim, "Inhibition of interleukin-12 production in lipopolysaccharide-activated macrophages by curcumin," $E u$ ropean Journal of Pharmacology, vol. 384, no. 2-3, pp. 191-195, 1999.

[12] B. Gupta and B. Ghosh, "Curcuma longa inhibits TNF- $\alpha$ induced expression of adhesion molecules on human umbilical vein endothelial cells," International Journal of Immunopharmacology, vol. 21, no. 11, pp. 745-757, 1999.

[13] P. M. Murphy and H. L. Tiffany, "Cloning of complementary DNA encoding a functional human interleukin-8 receptor," Science, vol. 253, no. 5025, pp. 1280-1283, 1991.

[14] J. Lee, R. Horuk, G. C. Rice, G. L. Bennett, T. Camerato, and W. I. Wood, "Characterization of two high affinity human interleukin-8 receptors," Journal of Biological Chemistry, vol. 267 , no. 23 , pp. 16283-16287, 1992.

[15] K. Asagoe, K. Yamamoto, A. Takahashi, et al., "Downregulation of CXCR2 expression on human polymorphonuclear leukocytes by TNF- $\alpha$," Journal of Immunology, vol. 160, no. 9, pp. 4518-4525, 1998.

[16] M. Baggiolini, B. Dewald, and B. Moser, "Human chemokines: an update," Annual Review of Immunology, vol. 15, pp. 675705, 1997.

[17] R. Feniger-Barish, M. Ran, A. Zaslaver, and A. Ben-Baruch, "Differential modes of regulation of CXC chemokine-induced internalization and recycling of human CXCR1 and CXCR2," Cytokine, vol. 11, no. 12, pp. 996-1009, 1999.

[18] J. J. Rose, J. F. Foley, P. M. Murphy, and S. Venkatesan, "On the mechanism and significance of ligand-induced internalization of human neutrophil chemokine receptors CXCR1 and CXCR2," Journal of Biological Chemistry, vol. 279, no. 23, pp. 24372-24386, 2004. 
[19] J. Barlic, M. H. Khandaker, E. Mahon, et al., " $\beta$-arrestins regulate interleukin-8-induced CXCR1 internalization," Journal of Biological Chemistry, vol. 274, no. 23, pp. 16287-16294, 1999.

[20] A. Chuntharapai and K. J. Kim, "Regulation of the expression of IL-8 receptor A/B by IL-8: possible functions of each receptor," Journal of Immunology, vol. 155, no. 5, pp. 2587-2594, 1995.

[21] R. M. Richardson, B. C. Pridgen, B. Haribabu, H. Ali, and R. Snyderman, "Differential cross-regulation of the human chemokine receptors CXCR1 and CXCR2. Evidence for timedependent signal generation," Journal of Biological Chemistry, vol. 273, no. 37, pp. 23830-23836, 1998.

[22] W. Yang, D. Wang, and A. Richmond, "Role of clathrinmediated endocytosis in CXCR2 sequestration, resensitization, and signal transduction," Journal of Biological Chemistry, vol. 274, no. 16, pp. 11328-11333, 1999.

[23] M. E. W. Hammond, G. R. Lapointe, P. H. Feucht, et al., "IL-8 induces neutrophil chemotaxis predominantly via type I IL-8 receptors," Journal of Immunology, vol. 155, no. 3, pp. 1428$1433,1995$.

[24] M. Bhattacharya, A. V. Babwah, and S. S. G. Ferguson, "Small GTP-binding protein-coupled receptors," Biochemical Society Transactions, vol. 32, part 6, pp. 1040-1044, 2004.

[25] J. S. Rodman and A. Wandinger-Ness, "Rab GTPases coordinate endocytosis," Journal of Cell Science, vol. 113, no. 2, pp. 183-192, 2000.

[26] M. Wilcke, L. Johannes, T. Galli, V. Mayau, B. Goud, and J. Salamero, "Rab11 regulates the compartmentalization of early endosomes required for efficient transport from early endosomes to the trans-golgi network," Journal of Cell Biology, vol. 151, no. 6, pp. 1207-1220, 2000.

[27] G.-H. Fan, L. A. Lapierre, J. R. Goldenring, J. Sai, and A. Richmond, "Rab11-family interacting protein 2 and myosin $\mathrm{Vb}$ are required for CXCR2 recycling and receptor-mediated chemotaxis," Molecular Biology of the Cell, vol. 15, no. 5, pp. 24562469, 2004.

[28] G.-H. Fan, L. A. Lapierre, J. R. Goldenring, and A. Richmond, "Differential regulation of CXCR2 trafficking by Rab GTPases," Blood, vol. 101, no. 6, pp. 2115-2124, 2003.

[29] W. Falk, R. H. Goodwin Jr., and E. J. Leonard, "A 48-well micro chemotaxis assembly for rapid and accurate measurement of leukocyte migration," Journal of Immunological Methods, vol. 33, no. 3, pp. 239-247, 1980.

[30] S. Ali, A. C. V. Palmer, S. J. Fritchley, Y. Maley, and J. A. Kirby, "Multimerization of monocyte chemoattractant protein-1 is not required for glycosaminoglycan-dependent transendothelial chemotaxis," Biochemical Journal, vol. 358, no. 3, pp. 737$745,2001$.

[31] B. J. Mounho, D. R. Davila, and S. W. Burchiel, "Characterization of intracellular calcium responses produced by polycyclic aromatic hydrocarbons in surface marker-defined human peripheral blood mononuclear cells," Toxicology and Applied Pharmacology, vol. 145, no. 2, pp. 323-330, 1997.

[32] S. W. Burchiel, B. S. Edwards, F. W. Kuckuck, et al., "Analysis of free intracellular calcium by flow cytometry: multiparameter and pharmacologic applications," Methods, vol. 21, no. 3, pp. 221-230, 2000.

[33] L. J. Picker, M. K. Singh, Z. Zdraveski, et al., "Direct demonstration of cytokine synthesis heterogeneity among human memory/effector T cells by flow cytometry," Blood, vol. 86, no. 4, pp. 1408-1419, 1995.

[34] S. Suzuki, M. Kobayashi, K. Chiba, et al., "Autocrine production of epithelial cell-derived neutrophil attractant-78 induced by granulocyte colony-stimulating factor in neutrophils," Blood, vol. 99, no. 5, pp. 1863-1865, 2002.

[35] I. Sabroe, T. J. Williams, C. A. Hébert, and P. D. Collins, "Chemoattractant cross-desensitization of the human neutrophil IL-8 receptor involves receptor internalization and differential receptor subtype regulation," Journal of Immunology, vol. 158, no. 3, pp. 1361-1369, 1997.

[36] R. M. Richardson, R. J. Marjoram, L. S. Barak, and R. Snyderman, "Role of the cytoplasmic tails of CXCR1 and CXCR2 in mediating leukocyte migration, activation, and regulation," Journal of Immunology, vol. 170, no. 6, pp. 2904-2911, 2003.

[37] D. Wu, G. J. LaRosa, and M. I. Simon, "G protein-coupled signal transduction pathways for interleukin-8," Science, vol. 261, no. 5117, pp. 101-103, 1993.

[38] R. H. Moore, E. E. Millman, E. Alpizar-Foster, W. Dai, and B. J. Knoll, "Rab11 regulates the recycling and lysosome targeting of $\beta_{2}$-adrenergic receptors," Journal of Cell Science, vol. 117, no. 15 , pp. 3107-3117, 2004.

[39] L. A. Volpicelli, J. J. Lah, G. Fang, J. R. Goldenring, and A. I. Levey, "Rab11a and myosin $\mathrm{Vb}$ regulate recycling of the M4 muscarinic acetylcholine receptor," Journal of Neuroscience, vol. 22, no. 22, pp. 9776-9784, 2002.

[40] S. Reddy and B. B. Aggarwal, "Curcumin is a non-competitive and selective inhibitor of phosphorylase kinase," FEBS Letters, vol. 341, no. 1, pp. 19-22, 1994.

[41] S. Anuchapreeda, P. Leechanachai, M. M. Smith, S. V. Ambudkar, and P.-N. Limtrakul, "Modulation of P-glycoprotein expression and function by curcumin in multidrug-resistant human KB cells," Biochemical Pharmacology, vol. 64, no. 4, pp. 573-582, 2002.

[42] H. Ligeret, S. Barthelemy, R. Zini, J.-P. Tillement, S. Labidalle, and D. Morin, "Effects of curcumin and curcumin derivatives on mitochondrial permeability transition pore," Free Radical Biology and Medicine, vol. 36, no. 7, pp. 919-929, 2004.

[43] T. Atsumi, Y. Murakami, K. Shibuya, K. Tonosaki, and S. Fujisawa, "Induction of cytotoxicity and apoptosis and inhibition of cyclooxygenase- 2 gene expression, by curcumin and its analog, $\alpha$-diisoeugenol," Anticancer Research, vol. 25, no. 6B, pp. 4029-4036, 2005.

[44] C. A. Dinarello, J. A. Gelfand, and S. M. Wolff, "Anticytokine strategies in the treatment of the systemic inflammatory response syndrome," Journal of the American Medical Association, vol. 269, no. 14, pp. 1829-1835, 1993. 


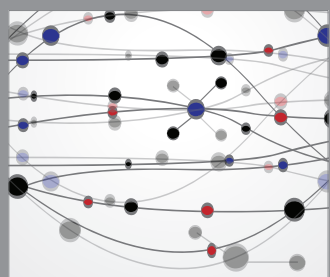

The Scientific World Journal
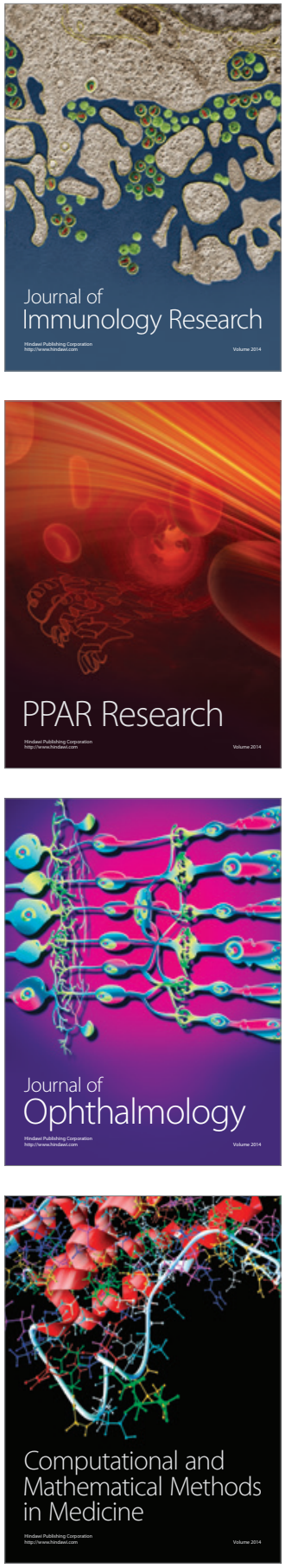

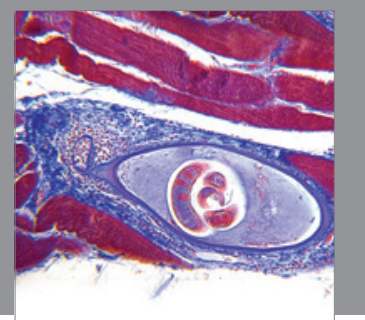

Gastroenterology

Research and Practice
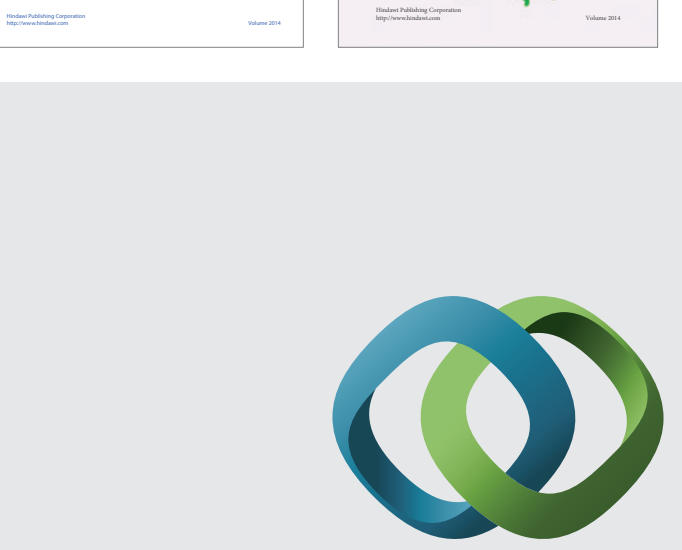

\section{Hindawi}

Submit your manuscripts at

http://www.hindawi.com
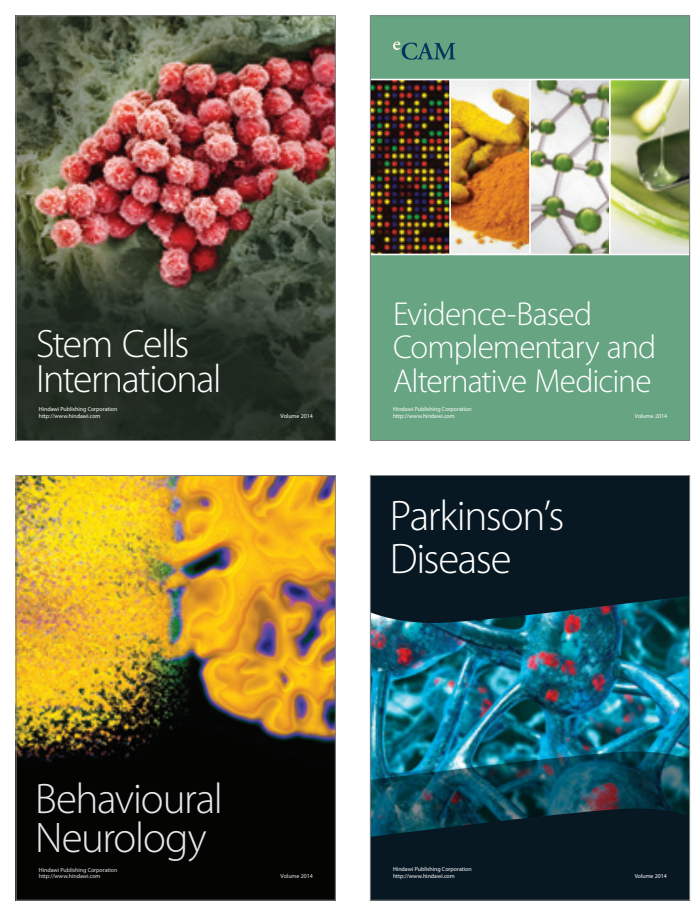

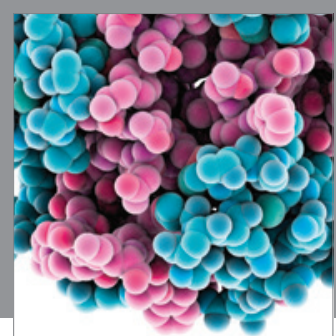

Journal of
Diabetes Research

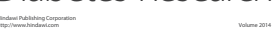

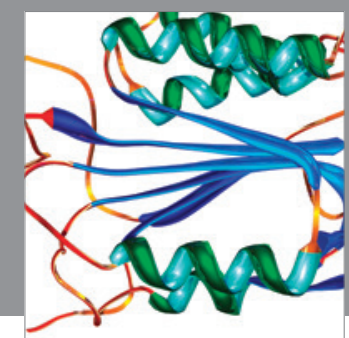

Disease Markers
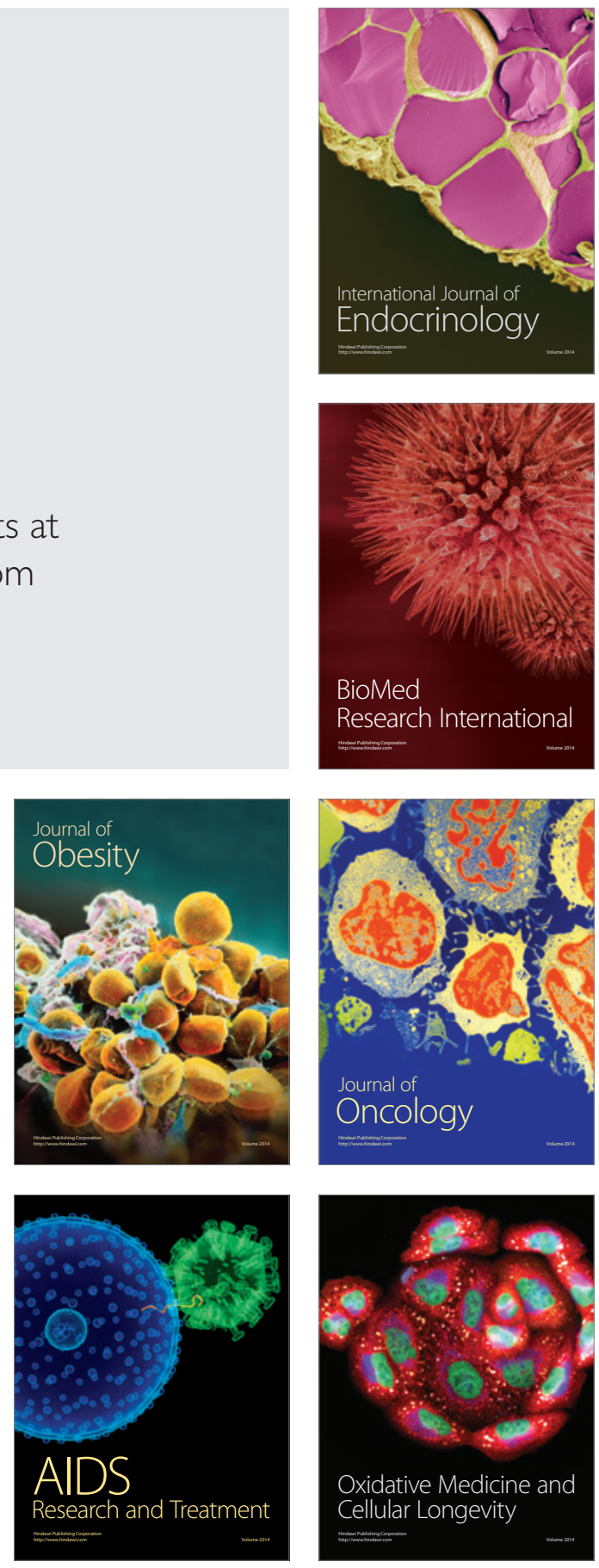